УДК 621.372 .8

\title{
ДИПЛЕКСЕР НА ЦИЛИНДРИЧЕСКОМ ВОЛНОВОДЕ С АНИЗОТРОПНЫМ ДИЭЛЕКТРИКОМ
}

\author{
СТРИЖАЧЕНКО А. В.
}

Харьковский национальньй университет, Украина, Харьков, 61077, пл. Свободы, 4

\begin{abstract}
Аннотация. Предложен диплексер, способный одновременно разделять сигналы сантиметрового диапазона длин волн по частотам, поляризациям и различным волноводным каналам и обладающий малыми массогабаритными параметрами и потерями сигнала в полосах пропускания
\end{abstract}

Ключевые слова: диплексер; резонансная частота; цилиндрический волновод; одноосный кристалл

\section{1. ВВЕДЕНИЕ}

Микроволновые диплексеры являются важными компонентами в системах спутниковой и мобильной связи. Они используются, чтобы передавать и получать сигналы единственной антенной. Диплексеры также используются, чтобы разделить сложный сигнал по двум различным каналам и передавать каждый сигнал отдельно. Из-за взаимодействия двух фильтров, составляющих диплексер, характеристики последнего могут отличаться от характеристик двух независимых фильтров.

В настоящее время наибольшее распространение нашли фильтры в виде волноводно-диэлектрических резонаторов и $T$-разветвлений [1-3], а также соединения $T X$ и $R X$ фильтров [4-8]. Недостатком таких диплексеров является сравнительно большие массогабаритные параметры.

Если сравнивать известные СВЧ фильтры по минимуму потерь при одинаковой ширине полосы пропускания или заграждения, то наилучшими показателями обладают волноводные фильтры. Это объясняется тем, что в сан- тиметровом диапазоне длин волн волноводные и волноводно-диэлектрические резонаторы имеют наибольшую собственную добротность.

Волноводные фильтры хорошо зарекомендовали себя в стационарной аппаратуре, где требования минимальных потерь сигнала имеют большее значение, чем массогабаритные показатели. Однако, для малогабаритной радиоэлектронной аппаратуры, применяемой в авиации, системах спутниковой связи и телевидения, массогабаритные показатели являются решающими факторами. В то же время накопленный опыт по миниатюризации СВЧ фильтров позволяет сделать вывод, что энергетические и массогабаритные показатели находятся в противоречии друг с другом [9].

В процессе поиска компромисса между этими показателями предлагаются фильтры на основе анизотропных диэлектриков. Анизотропия диэлектрической проницаемости, приобретаемая кристаллом в процессе роста, является в ряде случаев нежелательным свойством (сложность математического моделирования; уменьшение добротности резонаторов, запол- 